\title{
Thirty-day Outcomes in Indigenous Australians Following Coronary Artery Bypass Grafting
}

\begin{abstract}
Jessica O'Brien MB, BS ${ }^{\mathrm{a}}$, Akshat Saxena MB, BS ${ }^{\mathrm{b}}$, Christopher M. Reid PhD ${ }^{\mathrm{c}, \mathrm{d}}$, Lavinia Tran $\mathrm{PhD}^{\mathrm{c}}$, Robert Baker $\mathrm{PhD}^{\mathrm{e}}$, Andrew Newcomb MB, BS, FRACS ${ }^{\mathrm{f}}$, Julian Smith MB, BS, FRACS ${ }^{\mathrm{g}}$, Molla M. Huq ${ }^{\mathrm{c}}$, Stephen J. Duffy MB, BS, PhD, FRACP ${ }^{\mathrm{a}, \mathrm{c}}$.

${ }^{a}$ Department of Cardiovascular Medicine, The Alfred Hospital, Melbourne, Victoria,

${ }^{b}$ Discipline of Cardiothoracic Surgery, University of Sydney, Camperdown, NSW, ${ }^{c}$ Centre for Cardiovascular Research \& Education (CCRE) in Therapeutics, Monash University, Melbourne, Victoria ${ }^{\mathrm{d}}$ School of Public Health, Curtin University, Perth, Western Australia, ${ }^{\mathrm{e}}$ Cardiac \& Thoracic Surgical Unit, Flinders Medical Centre and Flinders University, Adelaide, South Australia, ${ }^{\mathrm{f}}$ Cardiothoracic Surgery, St Vincent's Clinical School Department of Surgery, University of Melbourne, ${ }^{\mathrm{g}}$ Departments of Surgery, Monash University and of Cardiothoracic Surgery, Monash Medical Centre, Melbourne, all in Australia.
\end{abstract}

Short title: Outcomes in Indigenous Australians Post CABG

Keywords: Indigenous Australians; ischaemic heart disease; coronary artery bypass grafting; outcomes

Word count: 3,760 (main text only: 1,584 words)

\section{Corresponding Author:}

Professor Stephen J. Duffy

Heart Centre, Alfred Hospital

Commercial Road

Melbourne 3004, Victoria, Australia

Telephone-61-3-9076.2732

Facsimile-61-3-9076.2461

This is the author manuscript accepted for publication and has undergone full peer review but has not been through the copyediting, typesetting, pagination and proofreading process, which may lead to differences between this version and the Version of Record. Please cite this article as doi: $10.1111 / \mathrm{imj} .13790$

This article is protected by copyright. All rights reserved. 
Email-s.duffy@alfred.org.au

This article is protected by copyright. All rights reserved. 


\begin{abstract}
Background

Indigenous Australians have higher rates of cardiovascular disease and co-morbidities compared to their non-Indigenous counterparts.
\end{abstract}

\title{
Aims
}

We sought to evaluate whether Indigenous status per se portends a worse prognosis following isolated coronary artery bypass grafting (CABG).

\section{Methods}

The outcomes of 778 Indigenous Australians (55 10 years; 32\% female) enrolled in the Australian and New Zealand Society of Cardiac and Thoracic Surgeons registry were compared to 36,124 non-Indigenous Australians (66 \pm 10 years; $21 \%$ female) following isolated CABG. In a secondary analysis, patients were propensity-matched by age, gender, renal function, diabetes, and ejection fraction (778 individuals in each group).

\section{Results}

Indigenous Australians were younger and more likely to be female, current smokers, to have diabetes, hypertension, renal impairment, heart failure, and previous $\mathrm{CABG}$ (all $\mathrm{p}<0.04$ ). Indigenous patients had fewer bypasses with arterial conduits (including less internal mammary artery use), and a higher number of distal vein anastomoses $(\mathrm{p}<0.001)$. Post-operative bleeding rates were higher in indigenous patients $(\mathrm{p}=0.001)$. However, in-hospital and 30-day all-cause mortality, and rates of 30-day readmission were similar between both groups, though cardiac mortality was higher

This article is protected by copyright. All rights reserved. 
in the Indigenous cohort $(1.5 \%$ vs. $0.8 \%, \mathrm{p}=0.02)$. With propensity-matching, rates of post-operative complications were similar amongst the two groups, with the exception of bleeding, which remained higher in Indigenous Australians $(\mathrm{p}=0.03)$.

\section{Conclusions}

Despite procedural differences and higher rates of baseline co-morbidities, Indigenous Australians do not have worse short-term outcomes following isolated CABG. Given the higher rates of baseline co-morbidities and lower rates of arterial conduit use, it will be essential to determine long-term outcomes.

This article is protected by copyright. All rights reserved. 


\section{INTRODUCTION}

The disparity between Indigenous and non-Indigenous Australians in terms of health outcomes is well recognized, with cardiovascular disease being the leading contributor to premature death in the Indigenous population $[1,2]$. Despite younger age at presentation with acute coronary syndromes, Indigenous patients have higher mortality rates than their non-Indigenous counterparts [3-5] potentially reflecting the increased prevalence of baseline co-morbidities, such as diabetes and obesity [6].

However, several studies suggest that the increased incidence and mortality of coronary artery disease (CAD) in Indigenous populations is not fully explained by the difference in traditional CAD risk factors [7, 8]. Geographical remoteness and reduced rates of coronary revascularization in Indigenous populations [3, 9-12] have been postulated to account for this increased mortality, though conflicting reports demonstrate comparable rate of CAD prevalence among urban Indigenous Australians compared with those in remote areas [13], and rates of revascularization similar to non-Indigenous Australians [14].

Given these disparate data, it is currently unclear whether Indigenous background itself portends a worse prognosis following acute coronary syndrome (ACS) or coronary revascularization.

This article is protected by copyright. All rights reserved. 
We aimed to establish whether Indigenous Australians had similar in-hospital and 30day outcomes to their non-Indigenous counterparts following isolated coronary artery bypass grafting (CABG). Furthermore, we endeavored to determine whether Indigenous status independently predicts outcome or is simply a marker of high-risk patients.

This article is protected by copyright. All rights reserved. 


\section{METHODS}

\section{Patient population}

We analysed the in-hospital and 30-day clinical outcomes in 36,902 consecutive patients undergoing isolated CABG between June 2001 and December 2012 at the 28 Australian hospitals contributing to the Australian and New Zealand Society of Cardiac and Thoracic Surgeons (ANZSCTS) Cardiac Surgery Database. Patients undergoing other cardiac surgery at the time of their CABG, such as valve replacement, were excluded. For the purpose of this study, patients were divided into two groups: those of Indigenous Australian origin and those of non-Indigenous origin. Patients were identified as Indigenous Australians in the ANZSCTS Registry by selfidentification or by notation in hospital administrative data (which are collected from each patient at admission). We then performed a secondary analysis where patients were propensity-matched $(1: 1)$ by age, gender, renal function, diabetes, and left ventricular ejection fraction (778 patients in each group).

\section{ANZSCTS Registry}

The ANZSCTS database contains detailed information pertaining to all cardiac surgery undertaken at participating hospitals. The database has been previously described in detail [15-17]. Briefly, demographic, clinical and procedural characteristics of consecutive patients undergoing cardiac surgery are prospectively recorded on case report forms using standardized definitions for all fields. The database is coordinated by the Centre of Cardiovascular Research and Education in 
Therapeutics, a research body within the Department of Epidemiology and Preventative Medicine (Monash University, Melbourne, Australia). The data are subject to an external quality audit program, performed on site to evaluate the completeness and accuracy of the database contents; data accuracy has been $97 \%$, which compares favorably to other large registries [16]. The Ethics Committee of each participating hospital had previously approved the use of de-identified patient data contained within the database for research and waived the need for individual patient consent ('opt-out consent') [15].

\section{Clinical Outcome Definitions}

Early post-operative outcomes were analysed. These included: in-hospital mortality; 30-day mortality; peri-operative myocardial infarction, defined as two or more of (1) enzyme level elevation, (2) new wall motion abnormality or (3) new Q waves on serial electrocardiograms; new renal failure, defined as two or more of (1) creatinine increased to $>0.2 \mathrm{mmol} / \mathrm{L},(2)$ a doubling or greater increase in creatinine over preoperative value or (3) a new requirement for dialysis/haemofiltration; prolonged ventilation, defined as ventilation for greater than 24 hours; deep sternal infection, defined as requiring wound debridement with one of positive culture or treatment with antibiotics; cardiac inotrope use for low cardiac output syndrome.

\section{Statistical analysis}

Continuous variables are expressed as mean $\pm \mathrm{SD}$, and categorical data are expressed as numbers/percentages. Continuous variables were compared using Student's $t$ test. 
Categorical variables were compared using Fisher's exact or chi-square tests as appropriate. Independent predictors of 30-day mortality were determined using multiple logistic regression models for variables with a $p$ value $<0.10$ in simple logistic regression models. All calculated $p$ values were 2 sided, and a p value $<0.05$ was considered significant. Statistical analysis was performed using Stata 12.0 (StataCorp, Texas, USA) and SPSS for Windows version 17.0 (SPSS, Munich, Germany).

\section{RESULTS}

\section{Baseline characteristics}

Indigenous Australians were younger and more likely to be female, current smokers, have diabetes mellitus, have higher baseline creatinine, hypertension, previous $\mathrm{CABG}$, recent thrombolysis and a family history of premature $\mathrm{CAD}$ ( $\mathrm{p}<0.03$ for all; Table 1). They were less likely to have a history of peripheral vascular and cerebrovascular disease $(\mathrm{p}<0.04$ for both), but there was no significant difference in body mass index (BMI) or history of chronic lung disease.

\section{Clinical presentation and procedural characteristics}

Indigenous Australians were less likely to present with an acute coronary syndrome as their indication for $\mathrm{CABG}$, and despite lower left ventricular ejection fraction

This article is protected by copyright. All rights reserved. 
(LVEF), were less likely to have New York Heart Association Class III or IV symptoms $(\mathrm{p}<0.002$ for all; Table 2). However, there was no difference in rates of pre-operative resuscitation, cardiogenic shock or use of inotropes or intra-aortic balloon pump.

Rates of left main disease were significantly lower in the Indigenous group $(p<0.001)$ though there was no difference in number of diseased vessels between the groups (Table 2). The Indigenous cohort had less internal mammary artery use as well as less arterial anastomosis use overall, but higher use of venous conduits (Table 3). They also had lower cross-clamp and cumulative cardiopulmonary bypass times $(\mathrm{p}<0.001)$.

\section{Outcomes}

Indigenous patients experienced more peri-operative MI but less post-operative renal impairment, arrhythmia and need for inotropes ( $p<0.04$ for all; Table 4$)$. There was no difference in the incidence of return to theatre, sternal wound infection or prolonged ventilation. At thirty-days, there was no difference in all-cause mortality, though cardiac death was higher in Indigenous Australians ( $1.5 \%$ vs. $0.8 \%, \mathrm{p}=0.02$; Table 5). Hospital re-admission rates were similar in both groups, though bleeding complications rates were higher in the Indigenous cohort $(4.1 \%$ versus $2.3 \%$, $\mathrm{p}=0.001)$.

This article is protected by copyright. All rights reserved. 
With propensity matching, all in-hospital and thirty-day outcomes were not significantly different between the groups with the exception of bleeding which remained higher in the Indigenous group ( $4.1 \%$ versus $2.2 \%, \mathrm{p}=0.03)$.

This article is protected by copyright. All rights reserved. 


\section{DISCUSSION}

In this multi-centre cohort study, Indigenous Australians were younger at presentation for isolated CABG with far higher rates of baseline comorbidities. Despite this, both groups had similar all-cause in-hospital and 30-day mortality, with varied postoperative complication rates, which, with the exception of increased bleeding in the Indigenous group, were comparable with propensity matching.

Our finding of Indigenous patients presenting for coronary bypass operation ten years earlier than their non-Indigenous counterparts is consistent with other reports [18-20]. Furthermore, the Indigenous cohort consisted of a higher percentage of female patients compared with the non-Indigenous group. It is now well documented that the pre-menopausal protection from CAD appears to be absent in Indigenous women [3, 5], though the reasons for this remain unclear. It is possible that the presence of multiple modifiable risk factors such as diabetes mellitus, dyslipidaemia, and smoking outweigh the protective effects of younger age and female gender.

We observed lower rates of arterial conduit use in Indigenous Australians, and in particular, internal mammary artery (IMA) use, which may be driven by lower rates of left main disease. Interestingly, the survival benefit expected from less left main coronary disease was not observed [21]. With propensity matching the difference in left main disease was no longer significantly different, but the lower rate of IMA use in Indigenous patients remained. Operator and institutional preference may account for this difference, with the majority of Indigenous patients receiving their CABG at 
the same few centres. Furthermore, Indigenous patients were more likely to have had prior CABG (12.5\% versus $6.1 \%)$, during which their IMA may have been utilized. The well-described superiority of arterial grafts over venous with regard to long-term patency and mortality [22-25] suggests that over time the IA cohort will have worse outcomes.

Increased rates of post-operative bleeding were observed in the Indigenous cohort. The recognized risk factors for post-CABG bleeding of low BMI, older age and female gender $[26,27]$ do not appear to account for this difference, as both groups had similar mean BMI and the increased bleeding persisted despite propensity matching for age and gender. Thrombolysis and emergency surgery are also unlikely contributors as initially increased rates of thrombolysis in Indigenous Australians became comparable with propensity matching and time from MI to CABG was longer for Indigenous compared to non-Indigenous Australians in both analyses. Preoperative hemoglobin, anti-platelet and anti-thrombotic use as well as history of clotting abnormalities are not recorded as part of the ANZSCTS registry but may account for some of the observed difference.

There are several limitations pertaining to our analysis. It is possible that we have underestimated the number of Indigenous Australian patients in our registry for several reasons. One is that some Indigenous Australians may not feel comfortable identifying themselves as Indigenous as they may feel treatment will be impacted. The second reason is there may be reluctance by administrative and medical staff to ask individual patients whether they identify as an Indigenous Australian. 
Nevertheless, this study reports a very large cohort of patients with known Indigenous status. Though re-admission and mortality are recorded at 30 days, rates of other complications, such as MI and stroke, are not. In view of the increased prevalence in Indigenous Australians of co-morbidities that may also contribute to these complications $[28,29]$ as well as concerns regarding medication adherence [30], it is possible that a difference in post-operative morbidity may exist between the groups despite similar mortality. While it is reassuring that outcomes following CABG are similar, we only have short-term results, and long-term outcomes may be worse in Indigenous Australians owing to greater baseline comorbidities and lower use of arterial conduits in their surgery.

\section{CONCLUSIONS}

Despite comparable rates of short-term outcomes, the higher prevalence of baseline co-morbidities as well as increased use of venous grafts in Indigenous Australians suggest that the two groups will diverge over time. Close follow-up and aggressive optimization of modifiable cardiovascular risk factors are crucial in ensuring that long-term outcomes are not worse for Indigenous Australians.

This article is protected by copyright. All rights reserved. 


\section{ACKNOWLEDGEMENTS}

Professor Duffy's \& Professor Reid's work is funded by National Health and Medical Research Council of Australia Grants. There are no conflicts of interest to declare.

This article is protected by copyright. All rights reserved. 


\section{REFERENCES}

1. AIHW 2015. The health and welfare of Australia's Aboriginal and Torres Strait Islander peoples: 2015. Cat. no. IHW 147. Canberra: AIHW.

2. Australian Health Ministers' Advisory Council. Aboriginal and Torres Strait Islander Health Performance Framework. 2012 report. Canberra: AHMAC, 2012.

3. Mathur S, Moon L, Leigh S. Aboriginal and Torres Strait Islander people with coronary heart disease: further perspectives on health status and treatment. Canberra: Australian Institute of Health and Welfare; 2006.

4. You J, Condon JR, Zhao Y, Guthridge S. Incidence and survival after acute myocardial infarction in Indigenous and non-Indigenous people in the Northern Territory. Med J Aust 2009; 190:298-302.

5. Katzenellenbogen JM, Sanfilippo FM, Hobbs MS, Briffa TG, Ridout SC, Knuiman MW, Dimer L, Taylor KP, Thompson PL, Thompson SC. Incidence of and case fatality following acute myocardial infarction in Aboriginal and non-Aboriginal Western Australians (2000-2004): a linked data study. Heart Lung Circ 2010; 19: 717-25.

6. Australian Aboriginal and Torres Strait Islander Health Survey: First Results, Australia, 2012-2013. Canberra: Australian Bureau of Statistics, 2014. (ABS Cat No. 4727.0.55.001)

7. Wang Z, Hoy WE. Hypertension, dyslipidaemia, body mass index, diabetes and smoking status in Aboriginal Australians in a remote community. Ethn

This article is protected by copyright. All rights reserved. 
Dis $2003 ; 13: 324-330$.

8. Wang Z, Hoy WE. Is the Framingham coronary heart disease absolute risk function applicable to Aboriginal people? Med J Aust 2005; 182: 66-69.

9. Cunningham J. Diagnostic and therapeutic procedures among Australian hospital patients identified as Indigenous. Med J Aust 2002; 176:58-62.

10. Coory MD, WF Walsh. Rates of percutaneous coronary intervention and bypass surgery after acute myocardial infarction in Indigenous patients. Med J Aust 2005; 182:507-12.

11. Randall DA, Jorm LR, Lujic S, O’Loughlin AJ, Eades SJ, Leyland AH. Disparities in revascularization rates after acute myocardial infarction between Aboriginal and non-Aboriginal people in Australia. Circulation 2013; 127:811-819.

12. Tavella R, McBride K, Keech W, Kelly J, Rischbieth A, Zeitz C, Beltrame JF, Tideman PA, Brown A. Disparities in acute in-hospital cardiovascular care for Aboriginal and non-Aboriginal South Australians. Med J Aust 2016; 205: 2227.

13. Bradshaw PJ, Alfonso HS, Finn JC, Owen J, Thompson PL. Coronary heart disease events in Aboriginal Australians: Incidence in an urban population. Med J Aust 2009; 190: 583-6.

14. Bradshaw PJ, Alfonso HS, Finn JC, Owen J, Thompson PL. The use of coronary revascularization procedures in urban Australian Aboriginals and a matched general population. Heart Lung Circ 2010; 19: 247-50.

This article is protected by copyright. All rights reserved. 
15. Chan W, Clark DJ, Ajani AE, Yap CH, Andrianopoulos N, Brennan AL, Dinh DT, Shardey GC, Smith JA, Reid CM, Duffy SJ. Progress towards a National Cardiac Procedure Database--development of the Australasian Society of Cardiac and Thoracic Surgeons (ASCTS) and Melbourne Interventional Group (MIG) registries. Heart Lung Circ, 2011. 20:10-8.

16. Andrianopoulos N, Dinh D, Duffy SJ, Clark DJ, Brennan AL, Chan W, Shardey GC, Smith JA, Yap C-H, Buxton BF, Ajani AE and Reid CM, on behalf of the Melbourne Interventional Group and Australasian Society of Cardiac and Thoracic Surgeons (ASCTS) Investigators. Quality control activities associated with registries in interventional cardiology and surgery. Heart, Lung, Circ, 2011;20:180-6.

17. Saxena A, Newcomb AE, Dhurandhar V, Bannon PG. Application of clinical databases to contemporary cardiac surgery practice: where are we now? Heart Lung Circ. 2016; 25: 237-242.

18. Matebele MP, Rohde S, Clarke A, Fraser JF. Cardiac surgery in Indigenous Australians: early onset cardiac disease with follow-up challenges. Heart Lung Circ 2014. 23: 566-571.

19. Wiemers P, Marney L, Muller R, Brandon M, Kuchu P, Kuhlar K, Uchime C, Kang D, White N, Greenup R, Fraser JF, Yadav S, Tam R. Cardiac surgery in Indigenous Australians - how wide is 'the gap'? Heart Lung Circ 2014; 23: 265-72.

This article is protected by copyright. All rights reserved. 
20. Prabhu A, Tully PJ, Bennetts JS, Tuble SC, Baker RA. The morbidity and mortality outcomes of Indigenous Australian peoples after isolated coronary artery bypass graft surgery: the influence of geographical remoteness. Heart Lung Circ 2013; 22: 599-605.

21. Ngaage DL, Sogliani F, Tang A. Early and late survival after surgical revascularization for left main coronary artery stenosis in stent era. $\mathrm{Br} \mathrm{J}$ Cardiol 2012;19:134-8.

22. Loop FD, Lytle BW, Cosgrove DM, et al. Influence of the internal mammary artery graft on 10-year survival and other cardiac events. N Engl J Med 1986; $314: 1$.

23. Cameron A, David KB, Green G, Schaff HV. Coronary bypass surgery with internal thoracic artery grafts - effect on survival over a 15 -year period. $\mathrm{N}$ Engl J Med 1996; 334:216

24. Shi WY, Hayward PA, Fuller JA, Tatoulis J, Rosalion A, Newcomb AE, Buxton BF. Is the radial artery associated with improved survival in older patients undergoing coronary artery bypass grafting? An analysis of a multicentre experience. Eur J Cardiothorac Surg. 2016 Jan;49(1):196-202.

25. Tatoulis J, Wynne R, Skillington PD, Buxton BF. Total arterial revascularization: achievable and prognostically effective-A multicenter analysis. Ann Thorac Surg. 2015 Oct;100(4):1268-75.

This article is protected by copyright. All rights reserved. 
26. Kartouti K, Cohen MM, McCluskey SA, Sher GD. A multivariate model for predicting the need for blood transfusion in patients undergoing first-time elective coronary bypass graft surgery. Transfusion $2001 ; 41: 1193$

27. Society of Thoracic Surgeons Blood Conservation Guideline Task Force, Ferraris VA, Ferraris SP, et al. Perioperative blood transfusion and blood conservation in cardiac surgery: the Society of Thoracic Surgeons and The Society of Cardiovascular Anaesthesiologists clinical practice guideline. Ann Thorac Surg 2007; 83:S27.

28. Thompson PL, Bradshaw PJ, Veroni M, Wilkes ET. Cardiovascular risk among urban Aboriginal people. Med J Aust 2003; 179:143-146.

29. Australian Institute of Health and Welfare 2011. The health and welfare of Australia's Aboriginal and Torres Strait Islander people, an overview 2011. Cat. no. IHW 42. Canberra: AIHW.

30. Hamrosi K, Taylor S J, Aslani P. Issues with prescribed medications in Aboriginal communities: Aboriginal Health Workers' perspectives. Rural Remote Health. 2006; 6:557-569

This article is protected by copyright. All rights reserved. 


\section{Tables}

Table 1: Baseline Characteristics of the Overall Cohort

\begin{tabular}{|l|c|c|c|}
\hline & $\begin{array}{c}\text { Indigenous } \\
\text { Australians } \\
\mathbf{n = 7 7 8}\end{array}$ & $\begin{array}{c}\text { Non- Indigenous } \\
\text { Australians } \\
\mathbf{n = 3 6 , 1 2 4}\end{array}$ & P value \\
\hline Age, years \pm SD & $54.6 \pm 10.4$ & $66.2 \pm 10.3$ & $<0.0001$ \\
\hline Female, $\mathrm{n}(\%)$ & $251 / 778(32)$ & $7,426 / 35,346(21)$ & $<0.0001$ \\
\hline Diabetes mellitus & $435 / 778(56)$ & $11,879 / 35,301(34)$ & $<0.0001$ \\
\hline $\begin{array}{l}\text { Insulin-requiring } \\
\text { DM }\end{array}$ & $134 / 778(17)$ & $3,124 / 35,346(8.8)$ & $<0.0001$ \\
\hline Hypertension & $642 / 778(83)$ & $27,976 / 35,299(79)$ & 0.026 \\
\hline Current smoker & $350 / 645(54)$ & $5,465 / 23,743(23)$ & $<0.0001$ \\
\hline $\begin{array}{l}\text { Family history of } \\
\text { CAD }\end{array}$ & $339 / 714(48)$ & $13,679 / 32,498(42)$ & 0.004 \\
\hline $\begin{array}{l}\text { Pre-op creatinine, } \\
\mu m o l / L \pm \text { SD }\end{array}$ & $136.1 \pm 173$ & $101.3 \pm 81$ & $<0.0001$ \\
\hline Dialysis & $60 / 778(7.7)$ & $494 / 35,306(1.4)$ & $<0.0001$ \\
\hline $\begin{array}{l}\text { Cerebrovascular } \\
\text { disease }\end{array}$ & $65 / 778(8.4)$ & $3,807 / 35,297(11)$ & 0.030 \\
\hline $\begin{array}{l}\text { Peripheral arterial } \\
\text { disease }\end{array}$ & $54 / 778(6.9)$ & $4,255 / 35,297(12)$ & 0.000 \\
\hline Respiratory disease & $104 / 778(13)$ & $4,308 / 35,299(12)$ & 0.327 \\
\hline BMI, kg/m ${ }^{2} \pm$ SD & $28.7 \pm 5.9$ & $28.6 \pm 4.9$ & 0.541 \\
\hline
\end{tabular}

Data are number (\%), unless otherwise stated. Abbreviations: $\mathrm{SD}=$ standard deviation; $\mathrm{DM}=$ diabetes mellitus; $\mathrm{CAD}=$ coronary artery disease; $\mathrm{BMI}=$ body mass index. Respiratory disease is defined as any chronic lung disease; with mild being on any chronic bronchodilator therapy, moderate on chronic oral steroid therapy aimed at lung disease, and severe a room air $\mathrm{pO}_{2}<60 \mathrm{mmHg}$ or $\mathrm{CO}_{2}>50 \mathrm{mmHg}$ or mechanical ventilation for chronic lung disease.

This article is protected by copyright. All rights reserved. 
Table 2: Preoperative Cardiac Status

\begin{tabular}{|c|c|c|c|}
\hline & $\begin{array}{c}\text { Indigenous } \\
\text { Australians } \\
\mathrm{n}=778 \\
\end{array}$ & $\begin{array}{c}\text { Non- Indigenous } \\
\text { Australians } \\
\text { n=36,124 }\end{array}$ & $P$ value \\
\hline \multirow{6}{*}{$\begin{array}{l}\text { MI [CABG timing } \\
\text { since MI event] } \\
\text { d } 6 \text { hours } \\
6-24 \text { hours } \\
\text { 1-7 days } \\
8-21 \text { days } \\
>21 \text { days }\end{array}$} & & & \multirow{6}{*}{$<0.0001$} \\
\hline & $10 / 560(1.8)$ & $329 / 18,908(1.7)$ & \\
\hline & $8 / 560(1.4)$ & $467 / 18,908(2.5)$ & \\
\hline & $84 / 560(15)$ & $4,615 / 18,908(24)$ & \\
\hline & $185 / 560(33)$ & $4,791 / 18,908(25)$ & \\
\hline & $273 / 560(49)$ & $8,703 / 18,908(46)$ & \\
\hline \multirow{2}{*}{$\begin{array}{l}\text { Angina type: } \\
\text { Stable } \\
\text { Unstable }\end{array}$} & $450 / 583(77)$ & $21,697 / 30,868(70)$ & \multirow{2}{*}{$<0.0001$} \\
\hline & $133 / 583(23)$ & $9,171 / 30,868(30)$ & \\
\hline $\begin{array}{l}\text { History of heart } \\
\text { failure }\end{array}$ & $142 / 778(18)$ & $4,963 / 35,283(14)$ & 0.001 \\
\hline $\begin{array}{l}\text { Heart failure at } \\
\text { current admission }\end{array}$ & $61 / 174(35)$ & $2,174 / 6,129(36)$ & 0.91 \\
\hline \multirow{2}{*}{$\begin{array}{l}\text { NYHA Class: } \\
\text { I or II } \\
\text { III or IV }\end{array}$} & $666 / 778(86)$ & $28,359 / 35,346(80)$ & \multirow[t]{2}{*}{$<0.0001$} \\
\hline & $112 / 778(14)$ & $6,987 / 35,346(20)$ & \\
\hline Cardiogenic shock & $6 / 778(0.8)$ & $588 / 35,296(1.7)$ & 0.052 \\
\hline $\begin{array}{l}\text { Resuscitation } \\
\text { within } 1 \text { hour pre- } \\
\text { op }\end{array}$ & $5 / 778(0.6)$ & $330 / 35,297(0.9)$ & 0.40 \\
\hline Arrhythmia & $51 / 778(6.6)$ & $3,238 / 35,286(9.2)$ & 0.01 \\
\hline Inotropes & $12 / 778(1.5)$ & $576 / 35,294(1.6)$ & 0.85 \\
\hline Previous CABG & $21 / 168(13)$ & $1,124 / 18,476(6.1)$ & 0.001 \\
\hline Previous PCI & $113 / 209(54)$ & $4,877 / 8,146(60)$ & 0.09 \\
\hline $\begin{array}{l}\text { Thrombolysis } \\
\text { (same admission) }\end{array}$ & $17 / 152(11)$ & $394 / 7,575(5.2)$ & 0.005 \\
\hline LVEF, $\% \pm \mathrm{SD}$ & $51.0 \pm 15$ & $55.1 \pm 13$ & $<0.0001$ \\
\hline $\begin{array}{l}\text { Left main stenosis } \\
>50 \%\end{array}$ & $133 / 777(17)$ & $9,389 / 35,272(27)$ & $<0.0001$ \\
\hline \multirow{4}{*}{$\begin{array}{l}\text { No. of diseased } \\
\text { vessels } \\
\text { One } \\
\text { Two } \\
\text { Three }\end{array}$} & & & \multirow{4}{*}{0.68} \\
\hline & $51 / 777(6.5)$ & $1,898 / 35,283(5.4)$ & \\
\hline & $174 / 777(22)$ & $8,159 / 35,283(23)$ & \\
\hline & $552 / 777(71)$ & $25,221 / 35,283(72)$ & \\
\hline
\end{tabular}

Data are number (\%), unless otherwise stated. Abbreviations: NYHA $=$ New York Heart Association dyspnoea scale.

This article is protected by copyright. All rights reserved. 


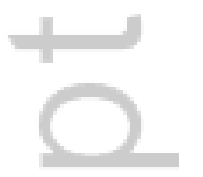

This article is protected by copyright. All rights reserved. 
Table 3: Coronary Bypass Data

\begin{tabular}{|c|c|c|c|}
\hline & $\begin{array}{c}\text { Indigenous } \\
\text { Australians } \\
\mathbf{n}=\mathbf{7 7 8}\end{array}$ & $\begin{array}{c}\text { Non- Indigenous } \\
\text { Australians } \\
\mathbf{n}=\mathbf{3 6 , 1 2 4}\end{array}$ & P value \\
\hline $\begin{array}{l}\text { Cumulative cross-clamp } \\
\text { time, min } \pm \text { SD }\end{array}$ & $50.3 \pm 27.6$ & $65.0 \pm 32.1$ & $<0.0001$ \\
\hline $\begin{array}{l}\text { Cumulative } \\
\text { cardiopulmonary bypass } \\
\text { time, min } \pm \text { SD }\end{array}$ & $78.2 \pm 37.8$ & $90.1 \pm 39.0$ & 0.0001 \\
\hline IABP & $44 / 777(5.7)$ & $1,969 / 35,303(5.6)$ & 0.92 \\
\hline Ventricular assist device & $0 / 775(0)$ & $51 / 35,302(0.1)$ & 0.29 \\
\hline IMA used & $684 / 777(88)$ & $33,208 / 35,333(94)$ & 0.0001 \\
\hline \multicolumn{3}{|c|}{ No. of anastomoses with arterial conduits } & \multirow{6}{*}{$<0.0001$} \\
\hline 0 & $129 / 777(16)$ & $1,877 / 35,327(5)$ & \\
\hline 1 & $501 / 777(65)$ & $12,202 / 35,327(35)$ & \\
\hline 2 & $80 / 777(10)$ & $9,685 / 35,327(27)$ & \\
\hline 3 & $45 / 777(6)$ & $7,404 / 35,327(21)$ & \\
\hline$>/=4$ & $22 / 777(3)$ & $4,159 / 35,327(12)$ & \\
\hline \multicolumn{3}{|c|}{ No. of anastomoses with venous conduits } & \multirow{6}{*}{$<0.0001$} \\
\hline 0 & $122 / 777(16)$ & $12,804 / 35,324(36)$ & \\
\hline 1 & $192 / 777(25)$ & $8,908 / 35,324(25)$ & \\
\hline 2 & $279 / 777(36)$ & $8,440 / 35,324(24)$ & \\
\hline 3 & $143 / 777(18)$ & $4,079 / 35,324(12)$ & \\
\hline$>/=4$ & $41 / 777(5)$ & $1,093 / 35,324(3)$ & \\
\hline
\end{tabular}

Data are number $(\%)$, unless otherwise stated. Abbreviations: IABP $=$ Intra-aortic balloon pump.

This article is protected by copyright. All rights reserved. 
Table 4: Post-op data

\begin{tabular}{|l|c|c|c|}
\hline & $\begin{array}{c}\text { Indigenous } \\
\text { Australians } \\
\mathbf{n = 7 7 8}\end{array}$ & $\begin{array}{c}\text { Non- Indigenous } \\
\text { Australians } \\
\mathbf{n = 3 6 , 1 2 4}\end{array}$ & P value \\
\hline Peri-procedural MI & $11 / 771(1.4)$ & $243 / 35,260(0.7)$ & $<0.0001$ \\
\hline Return to theatre & $46 / 774(5.9)$ & $1,723 / 35,286(4.9)$ & 0.18 \\
\hline $\begin{array}{l}\text { Inotropes for } \\
\text { longer than 4 hours }\end{array}$ & $237 / 759(31)$ & $11,508 / 28,209(41)$ & $<0.0001$ \\
\hline $\begin{array}{l}\text { Inotropes for low } \\
\text { cardiac output } \\
\text { syndrome }\end{array}$ & $126 / 759(17)$ & $5,552 / 28,306(20)$ & 0.04 \\
\hline $\begin{array}{l}\text { New cardiac } \\
\text { arrhythmia }\end{array}$ & $141 / 774(18)$ & $10,157 / 35,287(29)$ & $<0.0001$ \\
\hline $\begin{array}{l}\text { New renal } \\
\text { impairment }\end{array}$ & $16 / 774(2.1)$ & $1,223 / 35,284(3.5)$ & 0.04 \\
\hline $\begin{array}{l}\text { Deep sternal } \\
\text { wound infection }\end{array}$ & $9 / 774(1.2)$ & $228 / 35,285(0.6)$ & 0.08 \\
\hline $\begin{array}{l}\text { Ventilation }>24 \\
\text { hours }\end{array}$ & $72 / 774(9.3)$ & $2,965 / 35,286(8.4)$ & 0.37 \\
\hline
\end{tabular}

Data are number $(\%)$, unless otherwise stated. Abbreviations: $\mathrm{MI}=$ Myocardial infarction.

This article is protected by copyright. All rights reserved. 
Table 5: Outcomes

\begin{tabular}{|l|c|c|c|}
\hline & $\begin{array}{c}\text { Indigenous } \\
\text { Australians } \\
\mathbf{n = 7 7 8}\end{array}$ & $\begin{array}{c}\text { Non- Indigenous } \\
\text { Australians } \\
\mathbf{n = 3 6 , 1 2 4}\end{array}$ & P value \\
\hline Total mortality & $18 / 778(2.3)$ & $636 / 35,346(1.8)$ & 0.29 \\
\hline Cardiac death & $12 / 778(1.5)$ & $284 / 35,346(0.8)$ & 0.02 \\
\hline 30-day mortality & $15 / 717(2.1)$ & $538 / 35,059(1.5)$ & 0.23 \\
\hline $\begin{array}{l}\text { Bleeding } \\
\text { complication }\end{array}$ & $32 / 778(4.1)$ & $800 / 35,346(2.3)$ & 0.001 \\
\hline $\begin{array}{l}\text { 30-day hospital } \\
\text { readmission }\end{array}$ & $75 / 705(10.6)$ & $3,336 / 34,690(9.6)$ & 0.36 \\
\hline
\end{tabular}

Data are number (\%), unless otherwise stated. Bleeding complication is defined as bleeding requiring return to theatre.

This article is protected by copyright. All rights reserved. 


\section{University Library}

\section{- M M I N E R VA A gateway to Melbourne's research publications}

Minerva Access is the Institutional Repository of The University of Melbourne

Author/s:

O'Brien, J;Saxena, A;Reid, CM;Tran, L;Baker, RA;Newcomb, A;Smith, J;Huq, MM;Duffy, SJ

Title:

Thirty-day outcomes in Indigenous Australians following coronary artery bypass grafting

Date:

2018-07-01

Citation:

O'Brien, J., Saxena, A., Reid, C. M., Tran, L., Baker, R. A., Newcomb, A., Smith, J., Huq, M. M. \& Duffy, S. J. (2018). Thirty-day outcomes in Indigenous Australians following coronary artery bypass grafting. INTERNAL MEDICINE JOURNAL, 48 (7), pp.780-785. https:// doi.org/10.1111/imj.13790.

Persistent Link:

http://hdl.handle.net/11343/283674 